ISSN 2080-1653

DOI 10.24917/20801653.332.3

\author{
ZBigNIEW MiCHALIK \\ Uniwersytet Ekonomiczny w Krakowie, Polska \\ Cracow University of Economics, Poland
}

\title{
Trwałość przewagi konkurencyinej w sektorze fonograficznym w krajach Grupy Wyszehradzkiej
}

\section{The Sustainability of the Competitive Advantage in the Recording Industry in Visegrad Countries}

\begin{abstract}
Streszczenie: Sektor fonograficzny jest przykładem sektora oferującego dobra kulturalne. Podlega on ciągłej zmianie, związanej m.in. z przekształceniami wewnątrzstrukturalnymi, zachodzącymi w wyniku fuzji i przejęć, ze zmieniającą się liczbą nośników dźwięku i ich znaczeniem dla odbiorców, skutkującym malejącymi przychodami sektora w pierwszej dekadzie XXI wieku. Od kilku lat jest obserwowane odwrócenie tego trendu, wynikające z rosnącej sprzedaży muzyki w formie cyfrowej. Przedmiotem opracowania jest konkurencyjność produktów sektora fonograficznego. Celem opracowania jest przeprowadzenie analizy zmian trwałości pozycji konkurencyjnej fonogramów w układzie czasowym oraz w odniesieniu do fonogramów oferowanych na wybranych czterech rynkach: polskim, czeskim, słowackim oraz węgierskim, a więc krajów tworzących Grupę Wyszehradzką (Grupę V4) - grupę połączoną więziami gospodarczymi i politycznymi. Na podstawie analizy wartości wskaźnika trwałości przewagi konkurencyjnej fonogramu, jakim jest okres utrzymania dominującej pozycji na rynku, została podjęta próba weryfikacji tezy, zgodnie z którą okresy trwałości przewagi konkurencyjnej ulegają obecnie skracaniu. W opracowaniu zastosowano analizę danych rynkowych oraz miary statystyki opisowej. Zauważono, że w ramach Grupy V4 nie można mówić o jednolitym kierunku zmian trwałości przewagi konkurencyjnej fonogramów. Na rynku czeskim powyższa teza nie znajduje potwierdzenia. Różnice między rynkiem polskim i węgierskim dotyczą trwałości pozycji konkurencyjnej fonogramów reprezentujących różne gatunki muzyczne. Rekomendacje obejmują potencjalne kierunki zmian oraz wynikające z nich działania, które mogą zostać podjęte przez graczy sektora.
\end{abstract}

Abstract: The recording industry is an example of an industry offering cultural goods. It is subject to constant change, associated e.g. with intra-structural transformations taking place as a result of mergers and acquisitions, the changing number of formats and their importance to customers, resulting in declining revenues of the sector in the first decade of the 21st century. For several years, a reversal of this trend has been observed, resulting from the growing sales of music in digital form. The subject of the study is the competitiveness of the phonographic sector products. The aim of the study is to analyse changes in the sustainability of competitive position of phonograms in a timeframe and in relation to phonograms offered on four selected markets: Polish, Czech, Slovak and Hungarian, i.e. the countries forming the Visegrad Group. On the basis of the sustainability value of the phonogram's competitive advantage index, which is the period of maintaining the dominant position on the market, an attempt was made to verify the thesis that the periods of sustainability of competitive advantage are recently shortened. The analysis uses market data and measures of descriptive 
statistics. It was noted that within the V4 Group there is no same direction of changes in the sustainability of the competitive advantage of phonograms. On the Czech market, the above thesis is not confirmed. Differences between the Polish and Hungarian markets concern the durability of the competitive position of phonograms representing various musical genres. The applications relate to the potential directions of changes and the resulting activities that may be undertaken by enterprises in the sector.

Słowa kluczowe: Grupa V4; konkurencyjność; lista IFPI; lista MAHASZ; lista OLiS; sektor fonograficzny Keywords: competitiveness; IFPI chart; MAHASZ chart; OLiS chart; recording industry; V4 countries

Otrzymano: 18 grudnia 2018

Received: 18 December 2018

Zaakceptowano: 21 maja 2019

Accepted: 21 May 2019

\section{Sugerowana cytacja / Suggested citation:}

Michalik, Z. (2019). Trwałość przewagi konkurencyjnej w sektorze fonograficznym w krajach Grupy Wyszehradzkiej. Prace Komisji Geografii Przemysłu Polskiego Towarzystwa Geograficznego, 33(2), 31-44. doi: $10.24917 / 20801653.332 .3$

\section{WSTĘP}

Przewaga konkurencyjna jest jednym z głównych wyzwań stojących przed menedżerami odpowiedzialnymi za zarządzanie strategiczne. Z racji tego, że ma ona charakter względny, przewaga może być identyfikowana jedynie w wyniku porównania $\mathrm{z}$ konkurentami. Przedsiębiorstwo, jako podmiot konkurencji zachodzącej w gospodarce rynkowej, skupia szczególną uwagę badaczy. Tym niemniej analiza zachowań konkurencyjnych może zostać przeniesiona na poziom mezo (sektory jako podmioty konkurencji) lub makro (porównania między gospodarkami lub międzynarodowymi porozumieniami gospodarczymi). Gdy przeniesie się rozważania na grunt przedsiębiorstwa, konkurencyjność można odnieść do jednostek strategicznych i produktów (Pierścionek, 1996).

W przypadku sektora fonograficznego analiza konkurencyjności produktów znajduje szczególne uzasadnienie i to ona znajdzie się w centrum rozważań niniejszego opracowania, ponieważ na szczeblu przedsiębiorstw od kilku dekad mamy do czynienia z grupą przedsiębiorstw posiadających około 70-80\% udziału w rynku, których liczba zmniejszyła się z sześciu do trzech poprzez transakcje fuzji horyzontalnych, stawiających pytania o skuteczność przepisów antykoncentracyjnych (Wueller, 2013). Pozostałą część udziału w rynku posiada duża liczba małych, niezależnych przedsiębiorstw, określanych mianem indies. 0 ile nie mają one szans, by w najbliższym czasie zająć pozycję lidera rynkowego pod względem udziału w rynku, o tyle jest prawdopodobne, że wprowadzą na rynek produkty, które będą sprzedawać się lepiej od ofert potentatów sektora w danym okresie.

Tutaj pojawia się pojęcie przewagi konkurencyjnej jako systemu konkurencyjności przedsiębiorstwa, umożliwiającej generowanie atrakcyjnej oferty oraz skutecznych instrumentów konkurowania (Stankiewicz, 2002). 0 ile duże koncerny koncentrują swą uwagę na rynku globalnym, o tyle małe firmy mogą dążyć do osiągnięcia przewagi lokalnej, dzięki znajomości preferencji klientów połączonej z bezpośrednim kontaktem z nimi za pomocą mediów społecznościowych.

Operacjonalizacja przewagi konkurencyjnej w sektorze fonograficznym jest możliwa w oparciu o zestawienia najlepiej sprzedających się fonogramów w jednostce czasu. 
Podejście takie jest spójne z propozycją M.J. Stankiewicza, według którego pozycja konkurencyjna stanowi przejaw przewagi konkurencyjnej (Stankiewicz, 2002). Miejsce fonogramu w rankingu najlepiej sprzedających się płyt jest odzwierciedleniem jego pozycji konkurencyjnej.

Uwzględnianie zestawień sprzedaży w analizie zmian sytuacji na rynku fonograficznym było już stosowane w literaturze przedmiotu. Znaczenie list sprzedaży zostało dostrzeżone m.in. przez T. McCourta i E. Rothenbuhlera, którzy podkreślali ich rolę m.in. w procesie tworzenia strategii przedsiębiorstw fonograficznych czy planowania tras koncertowych poszczególnych artystów (McCourt, Rothenbuhler, 1997). J. Sernoe przeprowadził analizę danych publikowanych przez „Billboard” dla rynku amerykańskiego, ograniczając się jednak do zestawień rocznych, bez uwzględniania pojedynczych notowań. Dodatkowo, w centrum zainteresowania postawił popularność gatunków muzycznych, nie koncentrując się na pojedynczych tytułach. Zaproponował system punktacji w skali od 1 do 100, przy czym maksymalną wartość 100 punktów przyznawał albumowi, który zajął pierwszą pozycję w zestawieniu roku, a 1 punkt albumowi z setnego miejsca. Wyznacznikami przewagi konkurencyjnej gatunku były liczba albumów danego gatunku w zestawieniu oraz najwyższe miejsce albumu reprezentującego dany gatunek w zestawieniu (Sernoe, 2005).

W swoim opracowaniu J. Sernoe podjął także temat zmiany metodologii tworzenia listy „Billboardu”, dzieląc czasowy zakres analizy na dwa podokresy: 1981-1990 oraz 1992-2001, z pominięciem 1991 roku, w którym doszło do owej zmiany (Sernoe, 2005). Problem ten rozwinął w swym opracowaniu T. Harrison, który także w centrum uwagi postawił analizę gatunkową, ograniczając jednak swoje rozważania do muzyki hardrockowej i heavymetalowej (Harrison, 2007). Porównywał on miejsca wykonawców tego gatunku w cotygodniowych zestawieniach „Billboardu” pomiędzy drugim kwartałem 1990 roku a drugim kwartałem 1992 roku, dostrzegając malejącą ich popularność. Przyczyn upatrywał w zmianach gustów nabywców, rosnącej popularności muzyki grunge, ale także możliwości nieuczciwego kształtowania zestawień sprzedaży przed 1991 rokiem.

Problematykę porównywalności danych z list sprzedaży w związku ze zmianami metodologicznymi podjął także W.F. Carroll Jr., wskazując, że w kontekście analizy kariery konkretnego artysty należy poszukiwać równowagi między pozycją konkurencyjną jego fonogramu, mierzoną najwyższym miejscem na liście sprzedaży, a przewagą konkurencyjną, mierzoną liczbą tygodni spędzonych w zestawieniu (Carroll Jr., 2015).

Relacja między pozycją konkurencyjną fonogramu a dalszą karierą artysty stała się także przedmiotem badań 0. Haamplanda, który wykazał, że wysokie miejsce fonogramu na liście sprzedaży wpływa korzystnie na jego sprzedaż w przyszłości, ale zależność taka nie występuje w przypadku artystów (Haampland, 2017).

M. Lafrance, C. Scheibling, L. Burns i J. Durr poddali analizie listę „Billboardu”, badając wpływ czynników płci i koloru skóry na przewagę konkurencyjną. Wykazali, że czarnoskórzy artyści umieszczają swoje fonogramy na liście częściej niż artystki, bez względu na ich kolor skóry (Lafrance, Scheibling, Burns, Durr, 2018).

\section{METODYKA BADAŃ}

Analizą objęto dane dotyczące sprzedaży fonogramów na wybranych rynkach. Ze względu na dostępność danych są nimi płyty długogrające. Znaczenie nośników fizycznych 
jest szczególnie duże w Polsce, przy czym w skali globalnej jest dodatkowo zauważalny wzrost sprzedaży winyli (Smoleń, 2016; Mazurkiewicz, 2019). Metodyka badań została oparta na cytowanych w poprzedniej części opracowaniach, czyli fonogram jest traktowany jako produkt sektora, przy czym nie są uwzględniane np. czynniki emocjonalne mogące towarzyszyć klientowi przy dokonywaniu zakupu. Pozycja konkurencyjna jest wynikiem decyzji ogółu nabywców fonogramów w danym okresie.

Na potrzeby analizy trwałości pozycji konkurencyjnej fonogramów w niniejszym opracowaniu proponuje się uwzględnienie czterech wskaźników:

- $\mathrm{L}_{\mathrm{n}}$ - liczba nowości w zestawieniu,

- RR - rotacja fonogramów na danym rynku w okresie $t$,

- $\mathrm{RF}$ - rotacja fonogramów w zestawieniu,

- TPK - trwałość pozycji konkurencyjnej.

Pierwszy z nich, o ogólnym charakterze, odnosi się do liczby fonogramów $\mathrm{L}_{\mathrm{n}}$, które zyskały akceptację klientów i znalazły się po raz pierwszy, jako nowości, w zestawieniu najlepiej sprzedających się w danym okresie czasu albumów publikowanym przez powołaną do tego instytucję. Im wyższa wartość wskaźnika $\mathrm{L}_{\mathrm{n}}$, tym większa jest rotacja w zestawieniu, a tym samym trudniej jest wytwórni fonograficznej utrzymać w nim album. Wartość minimalna 0 świadczy o tym, że w danym okresie żadnemu albumowi spoza poprzedniego notowania (w tym pojawiającym się na rynku nowościom) nie udało się osiągnąć wolumenu sprzedaży większego od wolumenu sprzedaży każdego z fonogramów ujętych w poprzednim zestawieniu.

W celu porównania rotacji między różnymi okresami na tym samym rynku możliwe jest zastosowanie wskaźnika RR, stanowiącego iloraz średniej arytmetycznej liczby nowości w okresie $t$ oraz liczby albumów publikowanych w pojedynczym zestawieniu:

$$
R R=\frac{\frac{\sum_{i=1}^{n} L n}{n}}{L p}
$$

gdzie:

RR - rotacja fonogramów w okresie $t$,

$\mathrm{L}_{\mathrm{n}}$ - liczba nowości w zestawieniu,

$\mathrm{n}$ - liczba notowań w okresie $t$,

$\mathrm{L}_{\mathrm{p}}$ - liczba fonogramów publikowanych w zestawieniu.

Aby możliwe było porównywanie rotacji między różnymi rynkami, proponuje się uwzględnienie wskaźnika RF. Pokazuje on procentowy udział albumów, które po raz pierwszy znalazły się w zestawieniu najlepiej sprzedających się fonogramów, w łącznej liczbie fonogramów w zestawieniu. Może on zostać wyrażony wzorem:

$$
R F=\frac{L n}{L p} \times 100 \%
$$

gdzie:

$\mathrm{RF}$ - rotacja fonogramów w zestawieniu,

$\mathrm{L}_{\mathrm{n}}$ - liczba nowości w zestawieniu,

$\mathrm{L}_{\mathrm{p}}$ - liczba fonogramów publikowanych w zestawieniu.

Im wyższa wartość wskaźnika RF, tym większa jest rotacja w zestawieniu, a tym samym trudniej jest wytwórni fonograficznej utrzymać w nim album. Wartość minimalna 
0 świadczy o tym, że w danym okresie żadnemu albumowi spoza poprzedniego notowania (w tym opublikowanym po raz pierwszy nowościom) nie udało się osiągnąć wolumenu sprzedaży większego od wolumenu sprzedaży każdego z fonogramów ujętych w poprzednim zestawieniu.

Oprócz zmian pozycji konkurencyjnej w obrębie całego notowania zasadne jest przeanalizowanie zmian zachodzących w obrębie produktów, które dotarły do pierwszego miejsca listy sprzedaży. Podstawowym wskaźnikiem trwałości pozycji konkurencyjnej jest liczba notowań, w których dany fonogram zajmował pozycję lidera. Im większa liczba notowań, tym większa będzie trwałość pozycji konkurencyjnej. Aby zastosować ten wskaźnik do porównań międzyokresowych oraz rynkowych, proponuje się następującą jego konstrukcję:

$$
T P K=\frac{n}{L 1}
$$

gdzie:

TPK - trwałość pozycji konkurencyjnej, $\mathrm{n}$ - liczba notowań w okresie $t$, $\mathrm{L}_{1}$ - liczba fonogramów notowanych w okresie $t$ na pierwszym miejscu zestawienia.

Wartość wskaźnika mieszcząca się w przedziale [1,n] informuje, ile razy przeciętnie fonogramy były notowane w okresie $t$ na pierwszym miejscu zestawienia, a tym samym na ile trwała jest pozycja konkurencyjna w tym okresie.

Wyjściowym założeniem badań było objęcie analizą zmian trwałości pozycji konkurencyjnej na przestrzeni dwóch dekad, czyli lat 1998-2017. Istotnym ograniczeniem stała się dostępność danych. Jedynie dla Węgier było możliwe opracowanie bazy danych za cały okres, dla Polski za pełne 17 lat, dla Czech za 12 lat, natomiast dla Słowacji tylko za jeden rok. W związku z tym dla każdego z trzech pierwszych krajów analiza została przeprowadzona za okresy dostępności danych, natomiast analiza porównawcza została ograniczona do lat 2006-2017. Sytuacja na rynku słowackim została jedynie zasygnalizowana, przy założeniu kontynuacji badań i porównania z pozostałymi krajami V4 w perspektywie co najmniej kilku lat.

\section{TRWAŁOŚĆ PRZEWAGI KONKURENCYJNEJ NA POLSKIM RYNKU FONOGRAFICZNYM}

Polska jest największym rynkiem sprzedaży fonogramów wśród krajów Grupy Wyszehradzkiej, biorąc pod uwagę zarówno bezwzględną wartość sprzedaży, jak i wydatki na ofertę sektora przypadające na osobę (tabela 1).

Tabela 1. Sprzedaż produktów sektora fonograficznego w krajach Grupy V4

\begin{tabular}{|l|c|c|}
\hline \multirow{2}{*}{ Kraj } & $\begin{array}{l}\text { Wartość sprzedaży (mln dol. } \\
\text { amerykańskich) }\end{array}$ & $\begin{array}{l}\text { Wartość zakupów/osoba (dol. } \\
\text { amerykańskie) }\end{array}$ \\
\hline Polska & 375,6 & 3,2 \\
\hline Czechy & 31,9 & 3,1 \\
\hline Węgry & 24,9 & 2,5 \\
\hline Słowacja & 9,6 & 1,7 \\
\hline
\end{tabular}

Źródło: RIAJ Yearbook 2012... (2012: 24) 
Rycina 1. Wskaźnik rotacji fonogramów RR dla rynku polskiego w latach 2001-2017

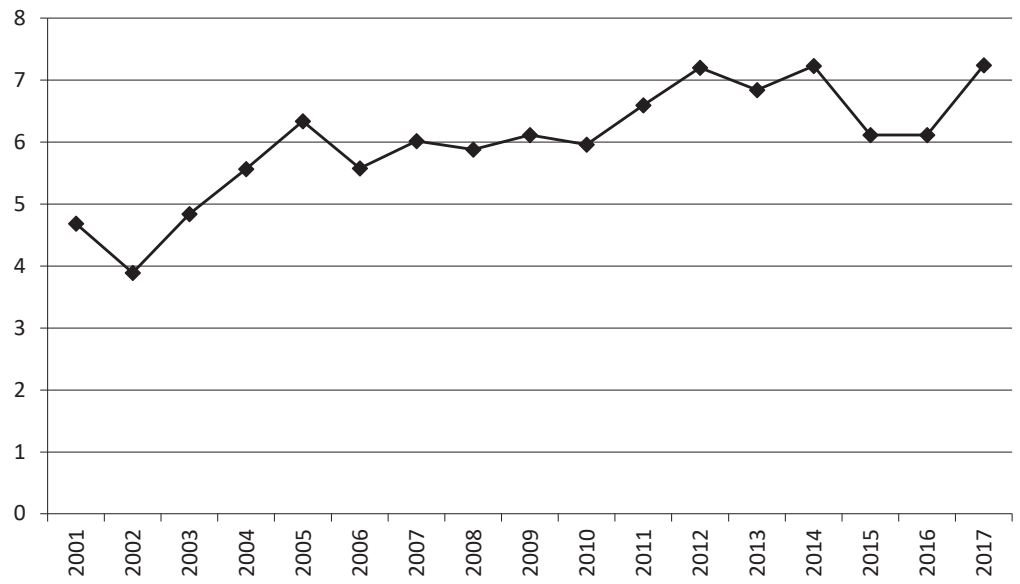

Źródło: opracowanie własne

Rycina 2. Trwałość pozycji konkurencyjnej na polskim rynku w latach 2001-2017 według gatunków muzycznych

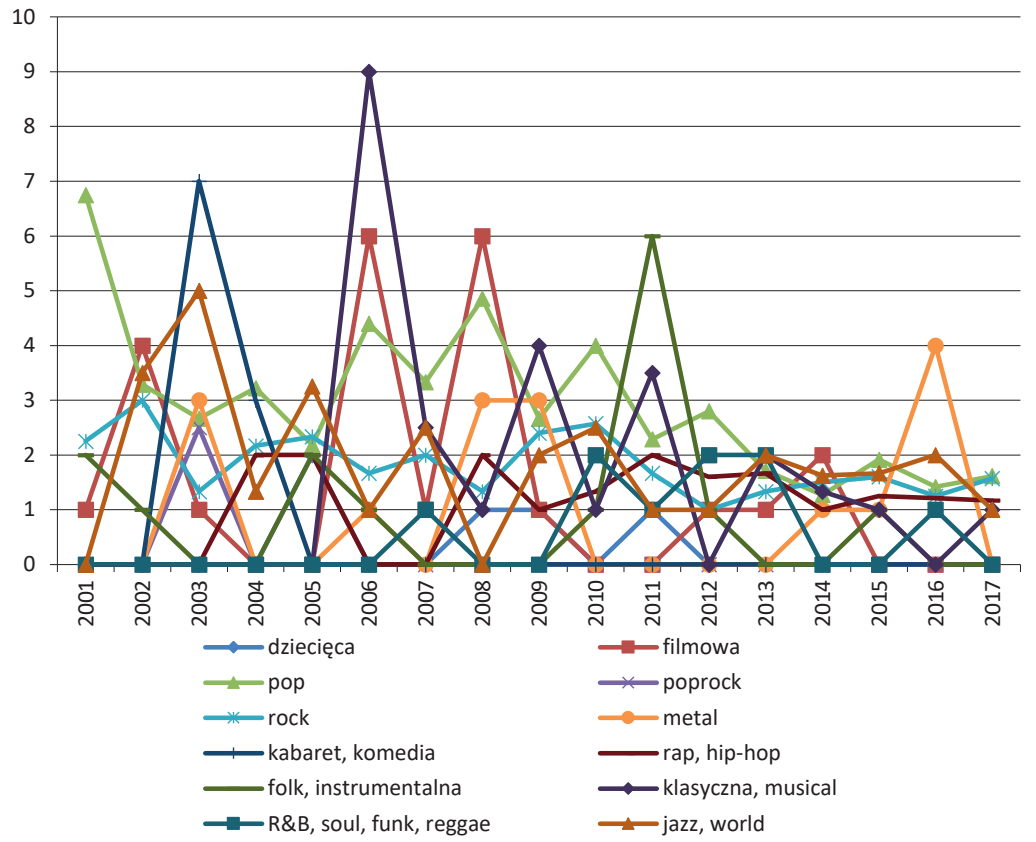

Źródło: opracowanie własne 
Zestawienie sprzedaży fonogramów w Polsce (OLiS - Oficjalna Lista Sprzedaży) jest publikowane przez Związek Producentów Audio-Video (ZPAV) od listopada 2000 roku. Na potrzeby analizy uwzględniono lata 2001-2017, dla których dostępne są zestawienia obejmujące wszystkie miesiące roku. OLiS obejmuje 50 najlepiej sprzedających się fonogramów w okresie następującym po poprzednim notowaniu. Zwykle jest to okres jednego tygodnia, ale zdarzają się wyjątki, związane przede wszystkim z okresami świątecznymi. Wówczas notowanie prezentuje dane dotyczące sprzedaży w ciągu dwóch tygodni. Sporadycznie zdarzały się przerwy 2-3-tygodniowe. Wskaźnik rotacji RR dla polskiego rynku fonograficznego jest przedstawiony na rycinie 1 .

W analizowanym okresie daje się zauważyć trend wzrostowy. W latach 20012003 pojawiało się w notowaniu OLiS przeciętnie mniej niż pięć nowych fonogramów. W latach 2004-2010 wskaźnik RR mieścił się w przedziale od 5,57 do 6,34. W 2012 roku po raz pierwszy przekroczył wartość 7 , by po dwóch latach na poziomie 6,12 osiągnąć maksimum wynoszące 7,24 . Trend wzrostowy oznacza, że na polskim rynku wydawcom jest coraz trudniej utrzymać fonogram wśród najlepiej sprzedających się 50 pozycji. Klienci są coraz bardziej skłonni, by zakupić produkt, który nie cieszył się dotychczas tak dużym powodzeniem. Warto podkreślić, że brak wcześniejszej akceptacji może wynikać z dwóch głównych przyczyn. Po pierwsze, na rynku pojawia się fonogram zawierający utwory skomponowane i nagrane w ostatnim czasie. Po drugie, mogą to być nagrania znane klientom, które miały premierę przed uruchomieniem listy OLiS i są wprowadzane na rynek ponownie, $\mathrm{w}$ formie reedycji lub nagrania zyskujące szerszą akceptację dzięki zmianie polityki cenowej wydawcy lub dystrybutora, której przejawem jest oferowanie klientowi przy stanowisku kasowym albumu w obniżonej cenie. Praktykę taką można zaobserwować w liczącej się na rynku sieci sprzedaży detalicznej.

Gdy analizuje się zmiany wskaźnika TPK na polskim rynku, jest dostrzegalna tendencja spadkowa (tabela 2). W poprzedniej dekadzie fonogramy utrzymywały się przeciętnie więcej niż trzy razy na pozycji lidera w latach 2001, 2002, 2006 i 2008. W obecnej dekadzie tylko w 2011 roku wartość TPK osiągnęła poziom 2,0, by następnie obniżyć się do poziomu około 1,5. Na polskim rynku jest widocznie skracanie okresu utrzymania pozycji konkurencyjnej. Wniosek ten znajduje potwierdzenie także w odniesieniu do podziału fonogramów, które dotarły do pierwszego miejsca listy sprzedaży ze względu na reprezentowany przez nie gatunek muzyczny (rycina 2).

W latach 2013-2017 tylko raz średnia długość przebywania fonogramów danego gatunku na pierwszym miejscu zestawienia osiągnęła wartość 4,0, był to album Metalliki w 2016 roku, który był jedynym numerem jeden z muzyką metalową w tym roku. Wysokie wartości we wcześniejszych latach były zazwyczaj także konsekwencją reprezentowania gatunku muzycznego przez jeden fonogram, na który popyt utrzymywał się na wysokim poziomie przez kilka tygodni. Były to odpowiednio: Kabaret TEY (19711980) w 2003 roku, Psałterz Wrześniowy i Tylko mnie kochaj w 2006 roku, Mamma Mia! w 2008 roku oraz Boso w 2011 roku.

\section{TRWAŁOŚĆ POZYCJI KONKURENCYJNEJ NA RYNKU FONOGRAFICZNYM CZECH I SŁOWACJI}

Czechy i Słowacja to dwa rynki, które łączą istotne z historycznego punktu widzenia relacje. Porównując je w kontekście funkcjonowania sektora fonograficznego, można zauważyć, że wartość sprzedaży fonogramów na rynku czeskim była ponad trzykrotnie 
Rycina 3. Wskaźnik rotacji fonogramów RR dla rynku czeskiego i słowackiego w latach 2001-2017

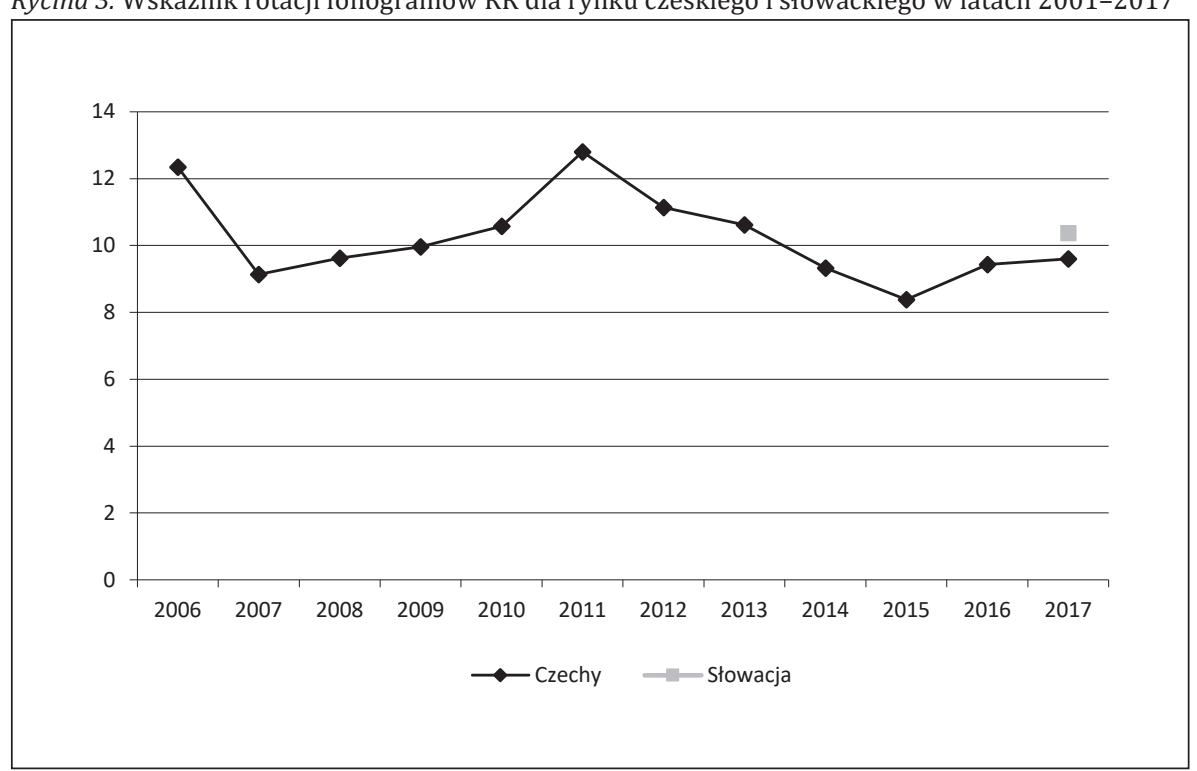

Źródło: opracowanie własne

Rycina 4. Trwałość pozycji konkurencyjnej na rynku czeskim w latach 2006-2017 według gatunków muzycznych

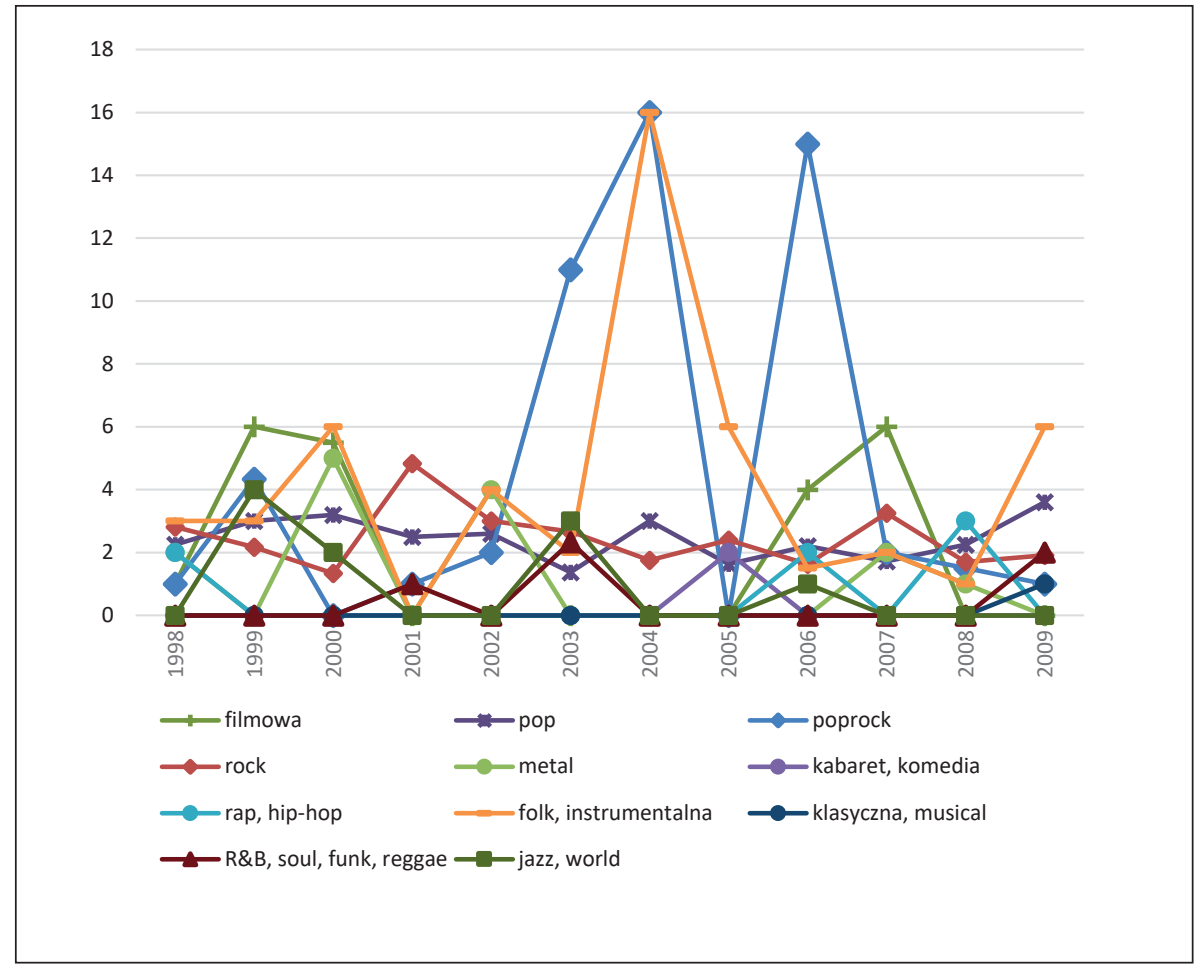

Źródło: opracowanie własne 
wyższa od wartości sprzedaży na rynku słowackim. Słowacy zdecydowanie najmniej wydawali w ramach Grupy Wyszehradzkiej na produkty sektora fonograficznego w przeliczeniu na jednego mieszkańca (tabela 1). Elementem łączącym te dwa kraje jest fakt, że publikowanie list sprzedaży fonogramów w Czechach i Słowacji leży w gestii czeskiego oddziału Międzynarodowej Federacji Przemysłu Muzycznego IFPI. Notowania dla Czech są dostępne od początku 2006 roku, dla Słowacji - od października 2016 roku, co oznacza, że analiza sytuacji na tym rynku jest możliwa tylko dla jednego pełnego roku. W przypadku Czech zestawienia obejmowały 50 najlepiej sprzedających się albumów do 23 notowania w 2014 roku, po czym od notowania 24 w 2014 roku publikuje się listę 100 pozycji. Także 100 pozycji zawiera lista słowacka. Wskaźnik rotacji RR dla czeskiego i słowackiego rynku fonograficznego jest przedstawiony na rycinie 3. Aby zminimalizować wpływ powiększenia czeskiego zestawienia z 50 do 100 pozycji, podwojono liczbę nowości w zestawieniach w okresie do czerwca 2014 roku, zwiększając jednocześnie wartość mianownika wskaźnika RR do 100. Dodatkowo w 2006 roku pominięto pierwsze zestawienie, składające się wyłącznie z nowości.

W przeciwieństwie do rynku polskiego, na rynku czeskim nie jest widoczna tendencja wzrostowa. Wartości wskaźnika RR w latach 2013-2017 są zbliżone do wartości z lat 2007-2010. Szczególnie duża rotacja w obrębie zestawienia była dostrzegalna w pierwszym roku jego funkcjonowania, co można wytłumaczyć dużymi wahaniami w obrębie zestawień, oraz w 2011 roku, gdy w aż siedmiu notowaniach liczba nowości wynosiła co najmniej 10, czyli minimum $20 \%$ ogółu notowanych albumów. Odnośnie do rynku słowackiego można dostrzec, że w 2017 roku wskaźnik RR kształtował się na wyższym poziomie od obserwowanego dla rynku czeskiego.

Analizując zmiany wskaźnika TPK na czeskim rynku, można zaobserwować tendencję spadkową, przy czym nie jest ona tak wyraźna, jak ma to miejsce na rynku polskim (tabela 2). Wartości TPK dla 2006 i 2017 roku różnią się nieznacznie, na spadek wskazuje porównanie lat 2007-2009 z latami 2013-2016. Na tle pozostałych wartości wyróżnia się wskaźnik 5,10 dla 2012 roku, kiedy do pierwszego miejsca zestawienia dotarło tylko 10 albumów, z których dwa, czyli Racek i Tak mě tu máš zajmowały pozycję lidera po 16 razy każdy. Zmiany trwałości pozycji konkurencyjnej dla poszczególnych gatunków muzycznych zostały przedstawione na rycinie 4.

Tabela 2. Wskaźnik trwałości pozycji konkurencyjnej TPK w latach 1998-2017 na analizowanych rynkach

\begin{tabular}{|c|c|c|c|c|}
\hline \multirow{2}{*}{ Rok } & \multicolumn{4}{|c|}{ Kraj } \\
\cline { 2 - 5 } & Polska & Czechy & Węgry & Słowacja \\
\hline 1998 & - & - & 3,79 & - \\
\hline 1999 & - & - & 3,25 & - \\
\hline 2000 & - & - & 3,25 & - \\
\hline 2001 & 3,43 & - & 3,47 & - \\
\hline 2002 & 3,13 & - & 4,25 & - \\
\hline 2003 & 2,63 & - & 3,71 & - \\
\hline 2004 & 2,52 & - & 4,42 & - \\
\hline 2005 & 2,38 & - & 5,20 & - \\
\hline 2006 & 3,13 & 2,45 & 3,71 & - \\
\hline 2007 & 2,63 & 3,19 & 3,47 & 3,25 \\
\hline 2008 & 3,40 & 3,47 & & - \\
\hline
\end{tabular}




\begin{tabular}{|l|l|l|l|l|}
\hline 2009 & 2,48 & 3,19 & 1,96 & - \\
\hline 2010 & 2,55 & 2,94 & 3,47 & - \\
\hline 2011 & 2,00 & 2,50 & 2,00 & - \\
\hline 2012 & 1,79 & 5,10 & 2,08 & - \\
\hline 2013 & 1,61 & 2,43 & 2,17 & - \\
\hline 2014 & 1,33 & 2,43 & 2,60 & - \\
\hline 2015 & 1,58 & 2,60 & 2,52 & 1,80 \\
\hline 2016 & 1,37 & 1,89 & 2,89 & 2,43 \\
\hline 2017 & 1,39 & 2,43 & 2,00 & \\
\hline
\end{tabular}

Źródło: opracowanie własne

Najbardziej trwała pozycja konkurencyjna została osiągnięta w 2012 roku przez dwa wyżej wymienione fonogramy, reprezentujące muzykę poprockową i folkową. Były one jedynymi albumami w swoim gatunku, które dotarły w tym roku do pierwszego miejsca, a ponieważ popyt na nie utrzymywał się na najwyższym poziomie przez kilkanaście tygodni, skutkowało to wartościami znacznie odbiegającymi od pozostałych obserwacji. Zbliżony wynik został osiągnięty dwa lata później przez kolejny fonogram z muzyką poprockową, Proměnamě, nagrany podobnie jak Racek przez Tomáša Klusa. Interesujący jest przypadek nagrań z muzyką filmową. Relatywnie rzadko zajmują one pozycję lidera rynku, tylko sześć w ciągu 12 lat, ale często zachowują tę pozycję przez 4-6 tygodni.

\section{TRWAŁOŚĆ POZYCJI KONKURENCYJNEJ NA WĘGIERSKIM RYNKU FONOGRAFICZNYM}

Węgierski rynek muzyczny zajmuje trzecią pozycję wśród krajów Grupy Wyszehradzkiej, zarówno pod względem wysokości przychodów, jak i wydatków przypadających na osobę. Lista sprzedaży jest publikowana przez Magyar Hangfelvétel-kiadók Szövetsége (MAHASZ - Węgierskie Stowarzyszenie Przemysłu Nagraniowego) od listopada 1990 roku, posiada więc najdłuższą tradycję wśród objętych analizą krajów. Wskaźnik rotacji RR dla rynku węgierskiego jest przedstawiony na rycinie 5.

Podobnie jak w przypadku rynku polskiego, na Węgrzech można zauważyć tendencję wzrostową, począwszy od 2005 roku. W latach 1999-2004 pojawiały się w notowaniu MAHASZ przeciętnie mniej niż trzy nowe fonogramy. W latach 2012-2017 wskaźnik RR mieścił się w przedziale od 3,94 do 4,94. Ta ostatnia wartość, osiągnięta w 2015 roku, uległa obniżeniu w ciągu dwóch kolejnych lat do poziomu 4,04, korzystnego z punktu widzenia wydawców, których albumy znalazły się w notowaniu.

Wskaźnik TPK dla węgierskiego rynku znajduje się w trendzie spadkowym (tabela 2), chociaż w latach 2011-2016 obserwowano powolny, systematyczny wzrost, zakończony jednak w 2017 roku powrotem do wartości z 2011 roku. Różnica, w szczególności względem polskiego rynku, polega na tym, że dla większości analizowanych okresów wartość wskaźnika TPK kształtowała się na wyższym poziomie, czyli albumy na Węgrzech przebywały przeciętnie dłużej na pozycji lidera rynkowego. Maksymalna wartość TPK dla Węgier wyniosła 5,20 w 2005 roku, dla Polski - 3,40 w 2008 roku. Jeszcze wyraźniej ta różnica jest widoczna przy uwzględnieniu gatunków muzycznych fonogramów, które w obu krajach dotarły do pierwszego miejsca zestawienia sprzedaży (rycina 6). 
Rycina 5. Wskaźnik rotacji fonogramów RR dla rynku węgierskiego w latach 1998-2017

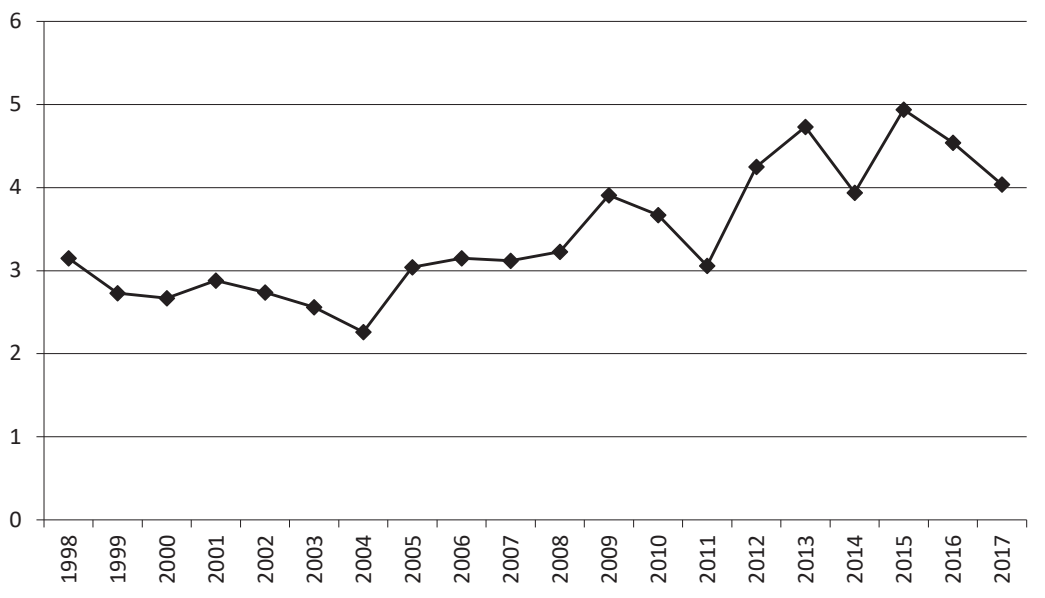

Źródło: opracowanie własne

Rycina 6. Trwałość pozycji konkurencyjnej na rynku węgierskim w latach 1998-2017 według gatunków muzycznych

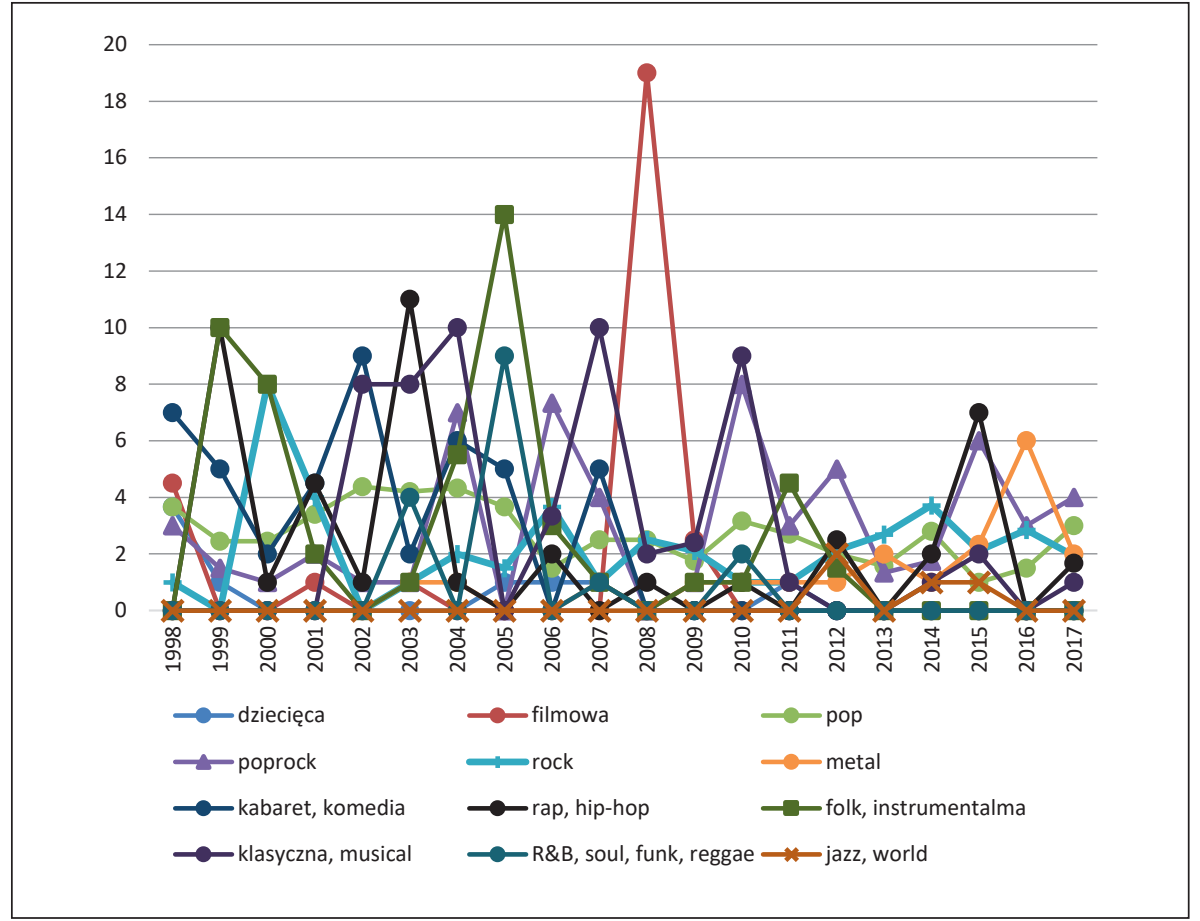

Źródło: opracowanie własne 
Rycina 7. Wartość wskaźnika RF na rynkach Grupy Wyszehradzkiej w latach 1998-2007 (w \%)

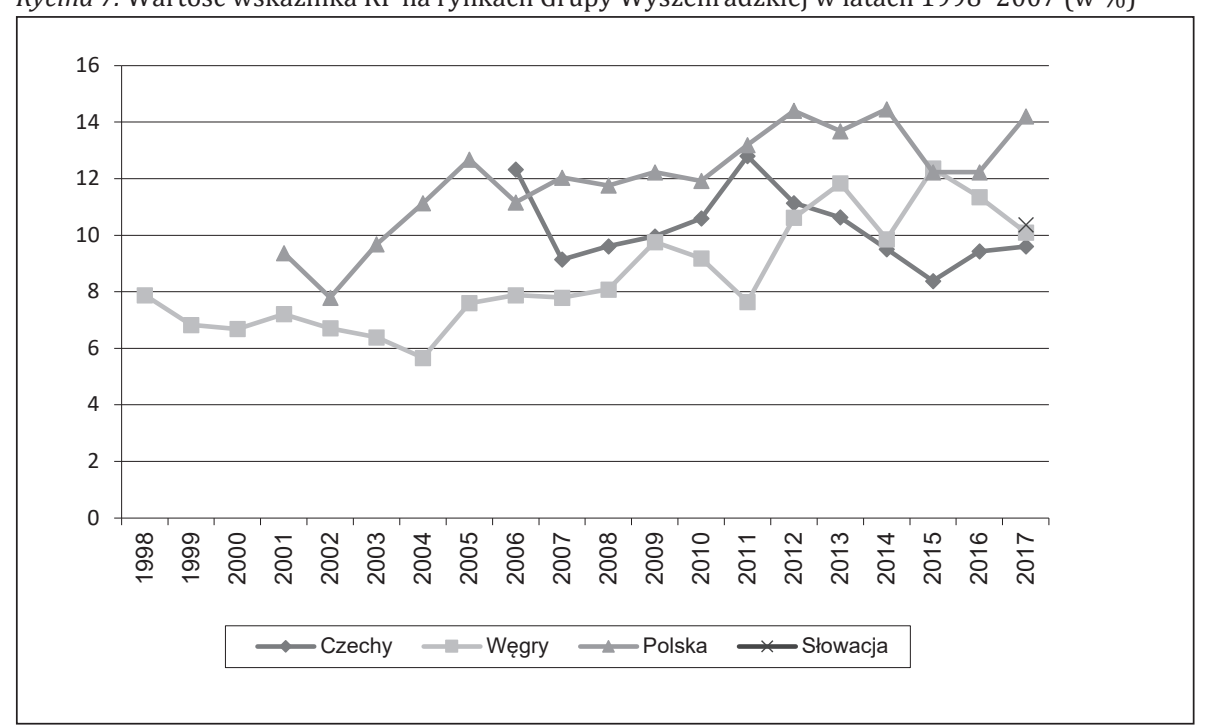

Źródło: opracowanie własne

O ile w Polsce odnotowano jedynie trzy przypadki, gdy wartość przeciętnej pozycji konkurencyjnej albumów w ramach konkretnego gatunku muzycznego wynosi powyżej 6, to dla Węgier takich przypadków w tym samym okresie, czyli w latach 2001-2017, było 14, z czego pięć dotyczyło albumów z muzyką klasyczną i musicalową ( $A$ hegedú hercegnői, Hegedűvarázs, Roméo \& Juliette, Musical Duett, A királyok hegedűse). Popularność muzyki tego gatunku jest cechą odróżniającą ten rynek od pozostałych rynków Grupy V4. Należy też podkreślić, że po 2010 roku tylko raz przeciętna przewaga konkurencyjna albumów jednego gatunku przekroczyła sześć notowań (muzyka rap, hip-hop w 2015 roku). Tym samym jest to argument przemawiający za skracaniem trwałości przewagi konkurencyjnej.

Porównanie zmian zachodzących na analizowanych rynkach przy zastosowaniu wskaźnika RF przedstawiono na rycinie 7.

Z powyższego rysunku wynika, że najwyższa rotacja fonogramów w obrębie list sprzedaży występuje w Polsce, z dwoma wyjątkami: w 2006 roku na czeskiej, a w 2015 roku na węgierskiej liście sprzedaży ponad 12\% stanowiły nowości. Gdy porównać rynki czeski i węgierski, w latach 2006-2012 większy odsetek nowości trafiał na czeską listę sprzedaży, podczas gdy od 2013 roku przewaga jest po stronie węgierskiego rynku. Znajduje to potwierdzenie we współczynniku korelacji między wartościami RF dla tych dwóch rynków w latach 2006-2017, wynoszącym -0,47, co świadczy o średniej ujemnej zależności między rotacją w zestawieniach sprzedaży fonogramów dla Czech i Węgier. Zależność między rynkiem czeskim i polskim jest nikła, współczynnik korelacji wynosi 0,07 , natomiast między rynkiem polskim i węgierskim jest słaba (współczynnik korelacji wynosi 0,36). Gdyby analiza dla ostatniej pary rynków została rozszerzona o lata 2001-2005, współczynnik korelacji wyniósłby 0,63 . Rosnące wartości wskaźnika RF świadczą o tym, że fonogramom jest trudniej zachować przewagę konkurencyjną wyrażającą się przynależnością do grupy najlepiej sprzedających się produktów na danym rynku. Niskie współczynniki korelacji 
wskazują na brak istotnej zależności między kierunkami zmian przewagi konkurencyjnej fonogramów na analizowanych rynkach.

\section{PoDsumOWANIE}

W sektorze fonograficznym, podobnie jak w każdym innym, stawia się pytania o konkurencyjność przedsiębiorstwa. Udział w rywalizacji rynkowej wyzwala w menedżerach dążenie do bycia najlepszym, pozycja lidera jest jednak z definicji zarezerwowana dla jednego przedsiębiorstwa. Dlatego pojawiają się propozycje, by - obok kompleksowej oceny konkurencyjności przedsiębiorstwa - odnosić ją do cząstkowych obszarów, jak np. produkty, ich cechy, strategie, zasoby. W sektorze fonograficznym kilka dekad temu zostały wdrożone propozycje wskazywania przewagi konkurencyjnej jego oferty, wśród których istotną funkcję pełni pozycja fonogramu w zestawieniu sprzedaży. W opracowaniu zaproponowano kilka wskaźników trwałości pozycji konkurencyjnej, które można odnieść zarówno do pojedynczego rynku, jak i zastosować w analizie porównawczej między różnymi rynkami. Na jej potrzeby w aspekcie geograficznym wybrano kraje Grupy Wyszehradzkiej, chociaż ze względu na szczątkowe dane z rynku słowackiego uwaga została skoncentrowana na Polsce, Czechach i Węgrzech.

Wskaźnik rotacji fonogramów w Polsce i na Węgrzech wykazuje tendencję wzrostową, co oznacza, że coraz trudniej jest utrzymać fonogram w grupie najlepiej sprzedających się na tych dwóch rynkach. Odwrotną sytuację obserwujemy w ostatnich latach w Czechach, gdzie wskaźnik rotacji uległ zmniejszeniu. Najwyższy odsetek nowości został odnotowany dla większości rocznych odcinków obserwacji na rynku polskim. Drugie miejsce w 2017 roku zajęła Słowacja, ale był to pierwszy rok funkcjonowania listy sprzedaży na tym rynku. Okres trwałości przewagi konkurencyjnej fonogramów, które znalazły się na pierwszym miejscu zestawienia sprzedaży w swoim kraju, ulega skracaniu na tych samych dwóch rynkach, na których rośnie wskaźnik rotacji: polskim i węgierskim. W Polsce został odnotowany spadek wskaźnika TPK z 3,43 w 2001 roku do 1,39 w 2017 roku, na Węgrzech z 3,79 w 1998 roku do 2,00 w 2017 roku. W Czechach, mimo wahań wskaźnika w okresie objętym badaniem, jego wartość w 2017 roku powróciła do poziomu z 2006 roku. Różnice między rynkiem polskim i węgierskim zostały zaobserwowane odnośnie do trwałości przewagi konkurencyjnej fonogramów reprezentujących poszczególne gatunki muzyczne. Na Węgrzech częściej niż w Polsce średnie okresy przewagi konkurencyjnej przekraczały poziom sześciu notowań sprzedaży. Wśród potencjalnych przyczyn można wskazać większy stopień kumulacji zakupów fonogramu w okresie poprzedzającym notowanie w przypadku Polski lub rozciągnięty w czasie proces przekonywania klientów węgierskich do zakupu fonogramu, który zdobył pozycję lidera rynkowego.

Odnośnie do przyszłych zmian stopnia trwałości pozycji konkurencyjnej fonogramów można stwierdzić, że scenariusz dalszego wzrostu wskaźnika rotacji RF jest realny. W analizowanym okresie jego wartość, z kilkoma wyjątkami, mieściła się w przedziale od $6 \%$ do 14\%, a trendowi wzrostowemu towarzyszyły korekty. Tym samym jest miejsce na jego dalszy wzrost w okolice poziomu $20 \%$ nowości w zestawieniu. 0 ile z perspektywy artysty korzystne jest zachowanie pozycji na liście sprzedaży, o tyle jego wydawcy może zależeć na wprowadzeniu kolejnego produktu do zestawienia. Brak konfliktu interesu jest obserwowany w zasadzie w przypadku najmniejszych podmiotów, gdy liczba publikowanych fonogramów jest niewielka i rozłożona w czasie. 
Wskaźnik TPK dla Polski osiągnął poziom 1,39 i jest bliski minimalnej wartości 1, wyrażającej skrajną nietrwałość osiągniętej pozycji konkurencyjnej i pojawianie się na szczycie zestawienia sprzedaży każdorazowo nowego fonogramu. Szczególnie małym firmom, którym udało się wprowadzić artystę na pierwsze miejsce, będzie trudno pozyskać nowych klientów w liczbie gwarantującej zachowanie tej lokaty. Niewątpliwie uzasadnione są dalsze badania tego sektora.

\section{Literatura \\ References}

Carroll Jr., W.F. (2015). Not So Lonely at the Top: Billboard \#1s and a New Methodology for Comparing Records, 1958-75. Popular Music and Society, 38(5), 586-610. doi: $10.1080 / 03007766.2014 .991188$

Haampland, O. (2017). Power Laws and Market Shares: Cumulative Advantage and the Billboard Hot 100. Journal of New Music Research, 46(4), 356-380. doi: 10.1080/ 09298215.2017 .1358285

Harrison, T. (2007). „Empire”: Chart Performance of Hard Rock and Heavy Metal Groups, 19901992. Popular Music and Society, 30(2), 197-225. doi: 10.1080/03007760701267730

Lafrance, M., Scheibling, C., Burns, L., Durr, J. (2018). Race, gender, and the Billboard Top 40 charts between 1997 and 2007. Popular Music and Society, 41(5), 522-538. doi: $10.1080 / 03007766.2017 .1377588$

Mazurkiewicz, P. (2019, 6 maja). Polska drugą Japonią. Hip-hop pompuje sprzedaż płyt. Rzeczpospolita. Pozyskano z https://cyfrowa.rp.pl/biznes/33850-polska-druga-japonia-hip-hop-pompuje-sprzedaz-plyt

McCourt, T., Rothenbuhler, E. (1997). SoundScan and the consolidation of control in the popular music industry. Media, Culture \& Society, 19, 201-218.

Pierścionek, Z. (1996). Strategie rozwoju firmy. Warszawa: Wydawnictwo Naukowe PWN.

RIAJ Yearbook 2012. Statistics. Trends. The Recording Industry in Japan (2012). Tokyo: Recording Industry Association of Japan.

Sernoe, J. (2005). "Now We're on the Top, Top of the Pops": The Performance of "NonMainstream" Music on Billboard's Albums Charts, 1981-2001. Popular Music and Society, 28(5), 639-662. doi: $10.1080 / 03007760500142670$

Smoleń, T. (2016). Wzrost sprzedaży płyt gramofonowych w II dekadzie XXI wieku - charakterystyka zjawiska sprzecznego z trendami światowego rynku fonograficznego. Handel Wewnętrzny, 62(4), 267-276.

Stankiewicz, M.J. (2002). Konkurencyjność przedsiębiorstwa. Toruń: Dom Organizatora.

Wueller, J.R. (2013). Mergers of Majors: Applying the Failing Firm Doctrine in the Recorded Music Industry. Brooklyn Journal of Corporate, Financial \& Commercial Law, 7(2), 589-612.

Zbigniew Michalik, dr, Uniwersytet Ekonomiczny w Krakowie, Katedra Przedsiębiorczości i Innowacji. Adiunkt w Katedrze Przedsiębiorczości i Innowacji Uniwersytetu Ekonomicznego w Krakowie. Jego zainteresowania badawcze obejmują przedsiębiorczość, zarządzanie strategiczne, konkurencyjność przedsiębiorstw. W ostatnim czasie koncentruje się na badaniach sektora fonograficznego.

Zbigniew Michalik, PhD, PhD, Cracow University of Economics, Department of Entrepreneurship and Innovativeness. His research interests include entrepreneurship, strategic management, competitive behaviours of companies. In recent years he has focused his research activity on the recording industry.

ORCID: 0000-0002-7188-6510

\section{Adres/address:}

Uniwersytet Ekonomiczny w Krakowie Katedra Przedsiębiorczości i Innowacji ul. Rakowicka 27, 31-510 Kraków, Polska e-mail: michaliz@uek.krakow.pl 